\title{
Evaluation of some biological properties of Saussurea costus crude root extract
}

\author{
Emad M. Abdallah, ${ }^{1 *}$ Kamal A. Qureshi, ${ }^{2}$ Ahmed M. H. Ali ${ }^{1,3}$ and Gamal O. Elhassan ${ }^{2}$ \\ ${ }^{1}$ Department of Laboratory Sciences, College of Sciences and Arts at Al-Rass, Qassim University, \\ Al-Rass, Saudi Arabia \\ ${ }^{2}$ Department of Pharmaceutics, Unaizah College of Pharmacy, Qassim University, Saudi Arabia \\ ${ }^{3}$ Department of Zoology and Entomology, Faculty of Science, Assiut University, Assiut, Egypt
}

\begin{abstract}
The current study aimed to evaluate some biological activities of Saussurea costus (S. costus) such as phytochemical constituents, antimicrobial activity and antifeedant potential on the larvae of Spodoptera littoralis. The results revealed that the methanol extract of roots of $S$. costus are rich in some bioactive phytochemical compounds such as alkaloids, phenols/polyphenols, flavonoids, terpenoids, tannins, coumarins, quinines, steroids, cardiac glycosides and resins. The antimicrobial screening revealed that, among 12 referenced microbial strains (10 bacteria and 2 fungi), 4 Gram-positive bacteria exhibited high susceptibility with the methanol and ethanol extracts of S. costus, namely Bacillus cereus ATCC 10876 (IZ 16.0 $\pm 0.0,15.5 \pm 0.5 \mathrm{~mm}$, MIC100, $50 \mathrm{mg} / \mathrm{ml}$, MBC 200, $100 \mathrm{mg} / \mathrm{ml}$ ), Staphylococcus

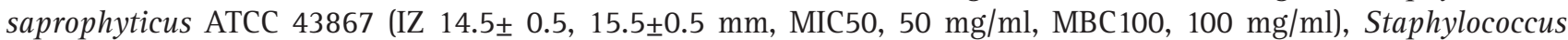
epidermidis ATCC 12228 (IZ 13.5 $\pm 0.5,14.5 \pm 0.5 \mathrm{~mm}$, MIC50, $50 \mathrm{mg} / \mathrm{ml}, \mathrm{MBC} 200,100 \mathrm{mg} / \mathrm{ml}$ ) and Staphylococcus aureus ATCC 29213 (IZ 11.0 $\pm 0.0,11.5 \pm 0.5 \mathrm{~mm}$, MIC 100, $50 \mathrm{mg} / \mathrm{ml}, \mathrm{MBC} 200,100 \mathrm{mg} / \mathrm{ml}$ ), respectively. Also, 1 fungal strain (Aspergillus niger ATCC 6275) revealed high susceptibility with the extracts (IZ $26.0 \pm 1.0 \mathrm{~mm}$, MIC and MFC $50 \mathrm{mg} / \mathrm{ml}$ ). Other microorganisms recorded weak or no effect. Furthermore, the ethanolic extract of S. costus provided an anitfeedant effect toward Spodoptera littoralis larvae at different concentrations. In conclusion, the current findings provide evidence that roots of Saussurea costus is rich in bioactive phytochemical compounds and it might be a promising source of antimicrobial compounds as well as antifeedant activity against the larvae of Spodoptera littoralis.
\end{abstract}

KEY WORDS: ANTIBACTERIAL, ANTIFUNGAL, PHYTOCHEMICAL, SAUSSUREA COSTUS, ANTIFEEDANT, INSECTICIDAL, SPODOPTERA LITTORALIS, TRADITIONAL MEDICINE

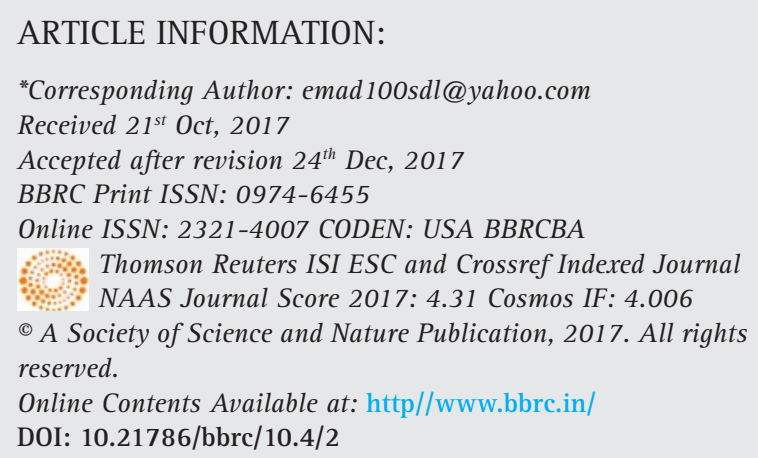




\section{INTRODUCTION}

Medicinal plants are used for healing purposes throughout the human history; even in the current era, there are up to $80 \%$ of the world population most of them are living in the developing countries, rely on traditional herbal medicine on their primary health care systems, many of these herbal drugs prescribed in traditional medicine have inadequate knowledge and untested by scientific methods (Ekor 2013 Qazi and Molvi 2016). On the other side, Modern medicine stands helpless in the front of the growing phenomenon of antimicrobial resistance to antibiotics, which considered as a major health problem and required prompt attention. This crisis encouraged scholars and researchers to develop the current antibiotics, synthesize new antibiotics or to find new alternatives. The latter option is preferable because, in nature, plants arise as one of the largest pharmaceutical factories ever known and plants were the main source of drugs for humankind since antiquity. Many medicinal plants produce diverse groups of secondary metabolites known as phytochemical compounds, which may suppress the microbial growth by different modes of action such as interference with cellular metabolic processes, cellular membrane perturbations or by modulating the signal transduction or gene expression pathways (Omojate et al., 2014 Mohamed et al. 2017).

Saussurea costus (Falc.) Lipschitz, synonymous with Saussurea lappa C.B. Clarke, belongs to family Asteraceae, this family includes about 1000 genera and 30,000 species, widely distributed in different regions in the world; However, numerous species are found in India (Pandey et al., 2007). It is also distributed in Pakistan and some parts of Himalayas (Shah 2006). Saussurea costus ( $S$. costus) is well known in Islamic medicine, which enlisted in the Holy Ahadith said by Prophet Muhammad (Peace be upon him) (Ahmad et al., 2009). It is known in Arab countries as "Al-Kost Al-Hindi" and used by traditional healers since the era of the Islamic civilization. For example but not limited to, S. costus is traditionally used as stimulant, antiseptic, carminative, sedative, bronchodilator and astringent agent (Wani et al., 2011). In the scientific literature, the biological activities of the roots of $S$. costus (synonymous with S. lappa) are widely investigated. Scientific investigations revealed that it has anti-trypanosomal activity (Julianti et al, 2011), it has "complement-inhibitor" substances helpful in the treatment of some diseases related to excessive activation of the complement system, like rheumatoid arthritis, respiratory distress and systemic lupus erythematosus (Fan et al., 2014). It was published that $S$. costus has a good anticancer activity on the tested cell lines (Robinson et al., 2008). The ethanol extract of $S$. lappa (synonymous $S$. costus) recorded a wide spectrum antimicrobial activity against some human pathogens (Hasson et al., 2013). In addition, many investigations reported other bioactive properties of $S$. costus roots such as anti-ulcer, anti-inflammatory, hepatoprotective, immunomodulator, hypoglycaemic, spasmolytic, anticonvulsant, antidiarrheal and antiviral activity (Zahra et al., 2014 Ghasham et al., 2017).

Egyptian cotton leafworm, Spodoptera littoralis (Lepidoptera: Noctuidae), is responsible for causing devastating damage for numerous vegetables and crops (Kandil et al., 2003; Adham, et al., 2009). This polyphagous pest is widely distributed in Africa and Middle Eastern countries (Abdel-Rahim and Azab 2008; Rizk et al. 2010; ElZoghby et al. 2011). Several synthetic pesticides have been used to manage the agriculture crops from insect infestation. These synthetic insecticides cause serious hazard to the environment due to residual toxicity (White, 1995; El- Torkey 2008; Rizk et al. 2010). Therefore, scientists developed safe alternative insecticides with no residual activity. In this regard, various phytochemical plant extracts from several botanical sources against the specific pest have been evaluated (Kamaraj et al., 2010). The current study aimed to investigate some biological properties of the methanol extract of the roots of $S$. costus, including the phytochemical constituents, antimicrobial activity and antifeedant potential on the larvae of Spodoptera littoralis.

\section{MATERIALS AND METHODS}

The dry roots of $S$. costus (Figure 1) were purchased from a herbal market at Qassim region, Saudi Arabia. The herbal seller showed the trademark of the package and it has been confirmed that it was exported from India. The authentication of plant material was confirmed at the department of Laboratory Sciences, College of Sciences and Arts, Al Rass, Saudi Arabia.

12 standard pathogenic test organisms were used in this study; Bacillus cereus ATCC ${ }^{\circledast} 10876^{\mathrm{TM}}$, Staphylococcus epidermidis ATCC $^{\infty} 12228^{\mathrm{TM}}$, Staphylococcus aureus ATCC $^{\circledast} 29213^{\mathrm{TM}}$, Staphylococcus saprophyticus ATCC $^{\circledast}$

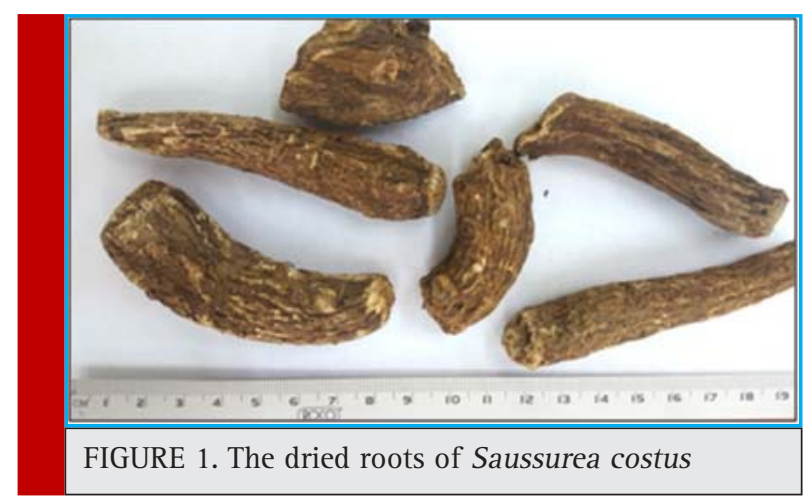


$43867^{\mathrm{TM}}$ and Streptococcus pneumonia ATCC $^{\oplus} 49619^{\mathrm{TM}}$, Escherichia coli ATCC $^{\circledast} 25922^{\mathrm{TM}}$, Proteus vulgaris ATCC $^{\circledast}$

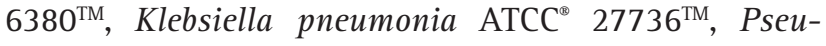
domonas aeruginosa $\mathrm{ATCC}^{\circledast} 9027^{\mathrm{TM}}$, Shigella flexneri ATCC $^{\oplus} 12022^{\mathrm{TM}}$, Candida albicans ATCC $^{\circledast} 10231^{\mathrm{TM}}$ and Aspergillus niger ATCC $^{\circledast} 6275^{\mathrm{TM}}$.

The extraction of plant material was carried out by following the maceration method. The roots of the plant were crushed into small particles and then fine powder was obtained by using electrical mixer grinder. The maceration of plant material was carried out by mixing of fine powder into $70 \%$ ethanol and $80 \%$ methanol solvents separately. Then, all mixtures were incubated in a shaker incubator at $40^{\circ} \mathrm{C}$ temp., 50 r.p.m. shaking speed for up to 3 days in a well-tighten dark container. After incubation, the mixtures were centrifuged at 5000 r.p.m. for 15 minutes and then filtered through Whatman filter paper No.1. The filtrates were subjected to evaporate the solvents by using a rotary evaporator to get a semi-solid mushy crude extract, which was dried in hot air oven at $45^{\circ} \mathrm{C}$ for $48 \mathrm{hrs}$. The dried crude extracts were kept in a refrigerator until used (Ghasham et al., 2017). Methanol crude extract was analyzed for potential phytochemical molecules, methanol and ethanol extracts were used in the antimicrobial investigation, while ethanol crude extract was employed in the antifeedant examination against the larvae of Spodoptera littoralis.

In order to detect the various phytochemical constituents, the aqueous methanolic extract $(100 \mathrm{mg} / \mathrm{mL})$ was used. The colourimetric tests listed below were used as reported by (Ghasham et al. 2017, Sasidharan et al., 2011).

$1 \mathrm{~mL}$ methanolic extract was mixed well with $1 \mathrm{~mL}$ of $1 \%$ hydrochloric acid solution, followed by slight heating till the steaming. After that, 06 drops of Wagner's reagent were added into $1 \mathrm{~mL}$ of acidified extract. The formation of a brownish-red precipitate was observed for a positive test.

\section{Carboxylic acid}

$2 \mathrm{~mL}$ of sodium bicarbonate solution was added to $1 \mathrm{~mL}$ of methanolic extract. The formation of effervescence was observed for a positive test.

\section{Cardiac glycosides}

$1 \mathrm{~mL}$ methanolic extract was dissolved in $1 \mathrm{~mL}$ of chloroform, followed by addition of 2-3 drops of the sulphuric acid solution at the side of the test tube to form a layer. The formation of a brown ring at interphase was observed for a positive test.

\section{Coumarins}

$1 \mathrm{~mL}$ of methanolic extract was mixed with $1 \mathrm{~mL}$ of 10 $\%$ sodium hydroxide solution. The formation of yellow colouration was observed for a positive test.

\section{Emodins}

$1 \mathrm{~mL}$ of ammonia and $1.5 \mathrm{~mL}$ of benzene solutions were added to $1 \mathrm{~mL}$ of methanolic extract. The formation of red colouration was observed for a positive test.

\section{Flavonoids}

$1 \mathrm{~mL}$ methanolic extract was added to $1 \mathrm{~mL}$ of $10 \%$ lead acetate solution. The formation of a yellow coloured precipitate was observed for a positive test.

\section{Leucoanthocyanins}

$1 \mathrm{~mL}$ of isoamyl alcohol was taken into a test tube, followed by slow addition of $1 \mathrm{~mL}$ of methanolic extract. The formation of red colouration at upper layer was observed for a positive test.

\section{Lipids}

$0.5 \mathrm{~mL}$ of methanolic extract was mixed with $5 \mathrm{ml}$ of ether. This mixture was allowed for evaporation on filter paper and dried the filter paper. The formation of an appearance of spot-on filter paper was observed for a positive test.

\section{Phenols/Polyphenols}

$1 \mathrm{~mL}$ methanolic extract was added into $0.5 \mathrm{~mL}$ of 10 $\%$ ethanolic ferric chloride solution. The formation of blue-green to dark blue colouration was observed for a positive test.

\section{Phlobatannins}

$1 \mathrm{~mL}$ methanolic extract was added to $1 \mathrm{~mL}$ of $1 \%$ hydrochloric acid solution, followed by boiling the mixture. The formation of a red precipitate was observed for a positive test.

\section{Quinones}

$1 \mathrm{~mL}$ of concentrated sulphuric acid was taken into a test tube, followed by addition of $1 \mathrm{~mL}$ of methanolic extract. The formation of red colouration was observed for a positive test.

\section{Resins}

Few drops of acetic anhydride solution were added to 1 $\mathrm{mL}$ of methanolic extract, followed by addition of $1 \mathrm{~mL}$ of concentrated sulphuric acid. The formation of orange to yellow colouration was observed for a positive test.

\section{Saponins}

$5 \mathrm{~mL}$ of purified distilled water was taken into a test tube, followed by addition of $1 \mathrm{~mL}$ of methanolic extract and the whole mixture was well stirred. The formation of continuous effervescence was observed for a positive test. 


\section{Steroids}

$1 \mathrm{~mL}$ methanolic extract was mixed with $1 \mathrm{~mL}$ of chloroform, followed by addition of $2 \mathrm{~mL}$ of acetic anhydride and then few drops of concentrated sulphuric acid solution. The formation of dark green colouration was observed for a positive test.

\section{Tannins}

2-3 drops of $1 \%$ lead acetate solution were added to 1 $\mathrm{mL}$ methanolic extract. The formation of dark blue or greenish grey colouration was observed for a positive test.

\section{Terpenoids}

$2.5 \mathrm{~mL}$ of methanolic extract was mixed with $1 \mathrm{~mL}$ of chloroform and then $1.5 \mathrm{~mL}$ of concentrated sulphuric acid solution was added. The formation of reddish brown colour at the interface was observed for a positive test.

\section{Volatile oil}

$0.5 \mathrm{~mL}$ of diluted sodium hydroxide and $0.5 \mathrm{~mL}$ of diluted hydrochloric acid were added to $2 \mathrm{~mL}$ of methanolic extract and mixed well. The formation of a white precipitate was observed for a positive test.

\section{ANTIMICROBIAL TESTING}

The antimicrobial potential of $S$. costus root extract was evaluated using agar-well diffusion method as described by (Abdallah, 2014) with some modifications. Before to the experimental phase, all identified microbial isolates were sub-cultured in a tighten bottles containing either Mueller-Hinton broth (18-24 hours, $\left.35{ }^{\circ} \mathrm{C}\right)$ for bacteria or Sabouraud dextrose broth ( 48 hours, $25{ }^{\circ} \mathrm{C}$ ) for fungi. After incubation, all turbid bottles- as a result of growth-were transferred and kept in the fridge $\left(4{ }^{\circ} \mathrm{C}\right)$ to keep the microbial growth at the exponential phase until used. Autoclaved Bottles containing $20 \mathrm{ml}$ of MuellerHinton agar or Sabouraud dextrose agar was poured hot on sterile Petri-dishes (90 $\mathrm{mm}$ in diameter) and left at room temperature until solidified. Working microbial strains were taken from the broth cultures (previously prepared) and adjusted as McFarland standard, then 100 $\mu \mathrm{l}$ from each microbial strain was put over Mueller-Hinton or Sabouraud dextrose agar plates (depending on the type of microorganism) and distributed above the agar using sterile cotton swabs. Wells were punched into the agar with a sterile cork borer (6 $\mathrm{mm}$ in diameter). Then, $100 \mu \mathrm{l}$ from each extract ( $500 \mathrm{mg} / \mathrm{ml}$ ) was dropped into the wells, extracts were previously reconstituted in 10\% di-methyl-sulphoxide (DMSO) to make a concentration $500 \mathrm{mg} / \mathrm{ml} .10 \%$ DMSO did not show any inhibitory effect on microorganisms. Another well (in the centre) was loaded with $100 \mu \mathrm{l}$ of $5 \mathrm{mg} / \mathrm{ml}$ Chloramphenicol for bacteria or $10 \mathrm{mg} / \mathrm{ml}$ clotrimazol for fungi. Plates were incubated at $35^{\circ} \mathrm{C}$ for 24 hours for bacteria or at $25^{\circ} \mathrm{C}$ for up to 48 hours for fungi. The antimicrobial activities of the tested extracts were determined by measuring the clear zone of inhibition in millimetre $(\mathrm{mm}) \pm$ standard error of the mean.

\section{MIC, MBC AND MFC ASSAY}

Only microorganisms that showed high antimicrobial activity was tested for MIC, MBC and MFC. The minimum inhibitory concentration (MIC) was determined using microdilution method as described by Hassan et al. (2009) with slight modification. Briefly, in a set of sterile test tubes, serial two-fold dilutions were made to get 6 tubes containing $1 \mathrm{ml}$ of 200, 100, 50, 25, 12.5 and $6.25 \mathrm{mg} / \mathrm{ml}$ of the extract, respectively. Additional two tubes were also used, one tube containing $1 \mathrm{ml}$ of $10 \%$ DMSO to serve as negative control and the other tube containing $1 \mathrm{ml}$ of $5 \mathrm{mg} / \mathrm{ml}$ chloramphenicol to serve as positive control. Then, $1 \mathrm{ml}$ of sterile Mueller-Hinton broth and $100 \mu$ l of the adjusted microbial strain were added to each tube (8 tubes). Tubes were gently shake and placed in the incubator at $35^{\circ} \mathrm{C}$ for 24 hours for bacteria or at $250 \mathrm{C}$ for up to 48 hours for fungi. The lowest concentration (highest dilution) of the extract that showed no visible microbial growth (no turbidity) compared with the control tubes was considered as MIC. The minimum bactericidal concentration (MBC) and minimum fungicidal concentration (MFC) was evaluated by determined by sub-culturing the test dilution on to unseeded plates of Mueller-Hinton agar for bacteria or Sabouraud dextrose agar for fungi and incubated further for $18-24 \mathrm{~h}$ for bacteria or $48 \mathrm{~h}$ for fungi. The highest dilution that revealed no single bacterial colony on the plates was taken as MBC or MFC.

\section{ANTIFEEDANT ASSAY AND STARVATION PERCENTAGE}

A strain of $S$. littoralis was reared in the laboratory. Larvae were fed on fresh castor leaves, Ricinus communius. Adults were provided with 10\% sugar solution. All the bioassays were conducted at $26 \pm 2^{\circ} \mathrm{C}$ and $65 \pm 5 \%$ R.H., with 8:16 L:D h photoperiod. The experiments were carried out on the 4th instar larvae. Serious of ascending crude concentrations were prepared (0.6 \%, $1.25 \%$, $2.5 \%, 5 \%, 10 \%$ and 20\%) by dilution in $70 \%$ ethanol. Control discs were sprayed with the solvent alone. 400 larvae were starved overnight, then divided into 8 groups of 50 larvae each, six different concentrations of plant extract $(S$. costus ), one group for the control and one group as starved larvae. Equal discs of castor bean leaves were rinsed in each treatment and in the control, the treated and untreated leaves were shad-dried. All 
larvae control and treated leaves were weighted before and after treatment for 3 days. The dried leaves were placed individually in plastic Petri dishes. Ten larvae were transferred into each cup and allowed to feed on the treated and untreated leaves, the starved larvae were left without feeding for $24 \mathrm{~h}$. Five replicates for each treatment were carried out. The starvation percentages of tested larvae were calculated (Mostafa 1969 ; AbdelMageed et al. 1975).

$$
\text { Starvation }(\%)=\mathrm{C}-\mathrm{E} / \mathrm{C}-\mathrm{S} \mathrm{X} 100
$$

Where:

$\mathrm{C}=$ Mean weight gain of untreated larvae after $24 \mathrm{~h}$;

$\mathrm{E}=$ Mean weight gain of treated larvae for each concentration after $24 \mathrm{~h}$; and

$\mathrm{S}=$ Mean weight gain of starved untreated larvae after $24 \mathrm{~h}$.

The antifeedant index (AFI) was calculated according to Sadek (2003).

$$
\text { AFI }(\%)=[(C-T) /(C+T)] X 100
$$

Where:

C: the amount of food consumed (leaves) in the control; and

T: the amount of food consumed (leaves) in the treatment.

\section{STATISTICAL ANALYSIS}

Quantitative data were expressed as a mean \pm standard error of means. One-way analysis of variance ANOVA was used and $\mathrm{P}<0.05$ was used in testing the statistical significance. Paired-Samples T-test was employed to determine any significant differences between methanol and ethanol extracts of the antimicrobial assay. The program used was SPSS-Statistical Package, version 11.

\section{RESULTS AND DISCUSSION}

\section{PHYTOCHEMICAL SCREENING}

The results of phytochemical screening suggest that, Saussurea costus roots are rich source of various bioactive constituents such as alkaloids, cardiac glycosides, coumarins, flavonoids, phenols, quinones, resins, steroids, tannins and terpenoids. These results are summarized in Table 1.

These phytochemical constituents are important for the use of health care. The findings of the present study agreed with previous studies; Chaudhary (2015) has reported that $S$. lappa (synonymous $S$. costus), is a rich source of alkaloids, steroids, flavonoids and resins. Moreover, Pandey et al., 2007 have reported that many bioactive molecules were identified and isolated from $S$.

\begin{tabular}{|l|l|}
\hline \multicolumn{2}{|l|}{ Table 1. phytochemical analysis of Saussurea } \\
costus roots \\
\hline Phytochemical constituents & Test results \\
\hline Alkaloids & + \\
\hline Cardiac glycosides & + \\
\hline Coumarins & + \\
\hline Flavonoids & + \\
\hline Phenol/Polyphenols & + \\
\hline Quinones & + \\
\hline Resins & + \\
\hline Steroids & + \\
\hline Tannins & + \\
\hline Terpenoids & + \\
\hline Carboxylic acid & - \\
\hline Leucoanthocyanins & - \\
\hline Lipids & - \\
\hline Emodins & - \\
\hline Phlobatannins & - \\
\hline Saponins & - \\
\hline Volatile oil & - \\
\hline + = test positive, - = test negative & \\
\hline & \\
\hline
\end{tabular}

costus, such as sesquiterpene lactones, costunolide, isodehydrocostus, isozaluzanin-C, guiainolide, cynaropicrin, reynosin, santamarine and many more. Undoubtedly, the diverse biological activities of $S$. costus are attributed to its richness in phytochemical compounds. Accordingly, it is recommended that more studies may lead to the understanding which molecules are responsible for the antibacterial, antifungal and antifeedant activities against Spodoptera littoralis larvae.

\section{ANTIMICROBIL SCREENING}

In the current study, $6 \mathrm{~mm}$ inhibition zone (IZ) means that there is no antimicrobial activity of the extract (the zone of the hole on the agar plate is $6 \mathrm{~mm}$ ), above $6 \mathrm{~mm}$ to less than $10 \mathrm{~mm}$ means that there is a weak antimicrobial activity, from $10 \mathrm{~mm}$ to $12 \mathrm{~mm}$ means that there is a moderate antimicrobial activity (the double of the hole diameter), above $12 \mathrm{~mm}$ is noticeable or good antimicrobial activity. Philip et al. (2009) considered that IZ above $10 \mathrm{~mm}$ is good antimicrobial activity. Unlike the antibiotics, there is no standard criterion in explaining the IZ for the crude plant extracts. The results of the antimicrobial activity are demonstrated in (Table 2) and (Figures 2-6). The results of the antimicrobial efficacy of methanolic and ethanolic extracts of $S$. costus roots have shown that Gram-positive bacteria were more susceptible. Bacillus cereus ATCC 10876 has recorded the highest susceptibility $(16.0 \pm 0.0,15.5 \pm 0.5 \mathrm{~mm})$, fol- 


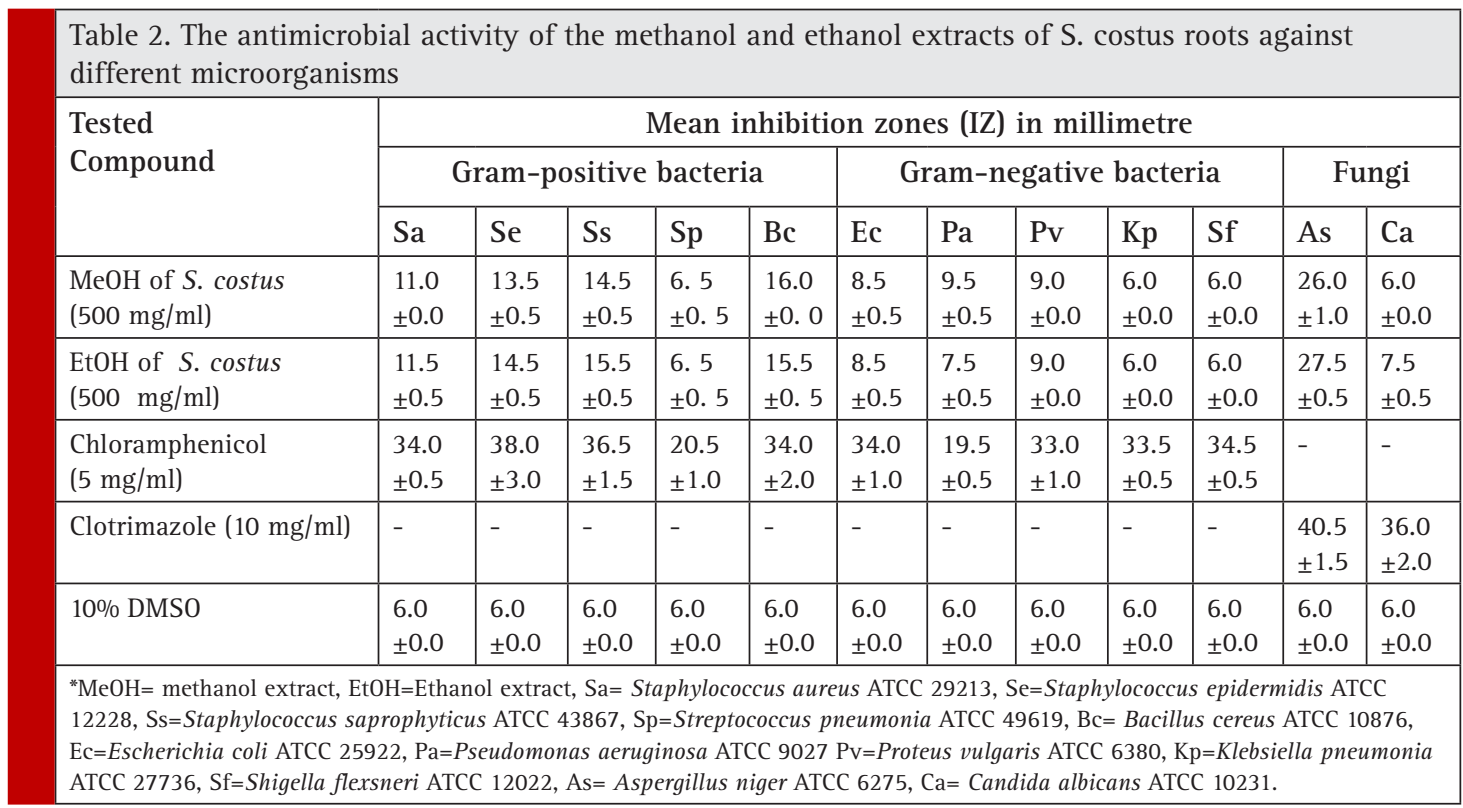

lowed by Staphylococcus saprophyticus ATCC 43867 $(14.5 \pm 0.0,15.5 \pm 0.5 \mathrm{~mm})$, Staphylococcus epidermidis ATCC $12228(13.5 \pm 0.5,15.5 \pm 0.5 \mathrm{~mm})$ and Staphylococcus aureus ATCC $29213(11.0 \pm 0.0,11.5 \pm 0.5 \mathrm{~mm})$, respectively. While, Streptococcus pneumonia ATCC 49619 has shown very weak susceptibility, which was $6.5 \pm 0.5$ $\mathrm{mm}$ for methanolic and ethanolic extracts. On the other side, the Gram-negative bacteria exhibited weak or no susceptibility at all. Weak susceptibility was found with Pseudomonas aeruginosa ATCC 9027 (9.5 $\pm 0.5,7.5 \pm 0.5$ $\mathrm{mm})$, Proteus vulgaris ATCC $6380(9.0 \pm 0.0,9.0 \pm 0.0 \mathrm{~mm})$ and Escherichia coli ATCC $25922(8.5 \pm 0.5,8.5 \pm 0.5 \mathrm{~mm})$ for methanolic and ethanolic extracts, respectively.

While, Klebsiella pneumonia ATCC 27736 and Shigella flexneri ATCC 12022 revealed no susceptibility against the tested extract, which agrees with the results of Mohamed et al. (2017) who stated that, methanolic extract of $S$. costus roots has significant level of antibacterial activity against Staphylococcus aureus and Bacillus subtilis (Gram-positive) and showed no effect against Escherichia coli and Pseudomonas aeruginosa (Gram-negative). Interestingly, these results are in

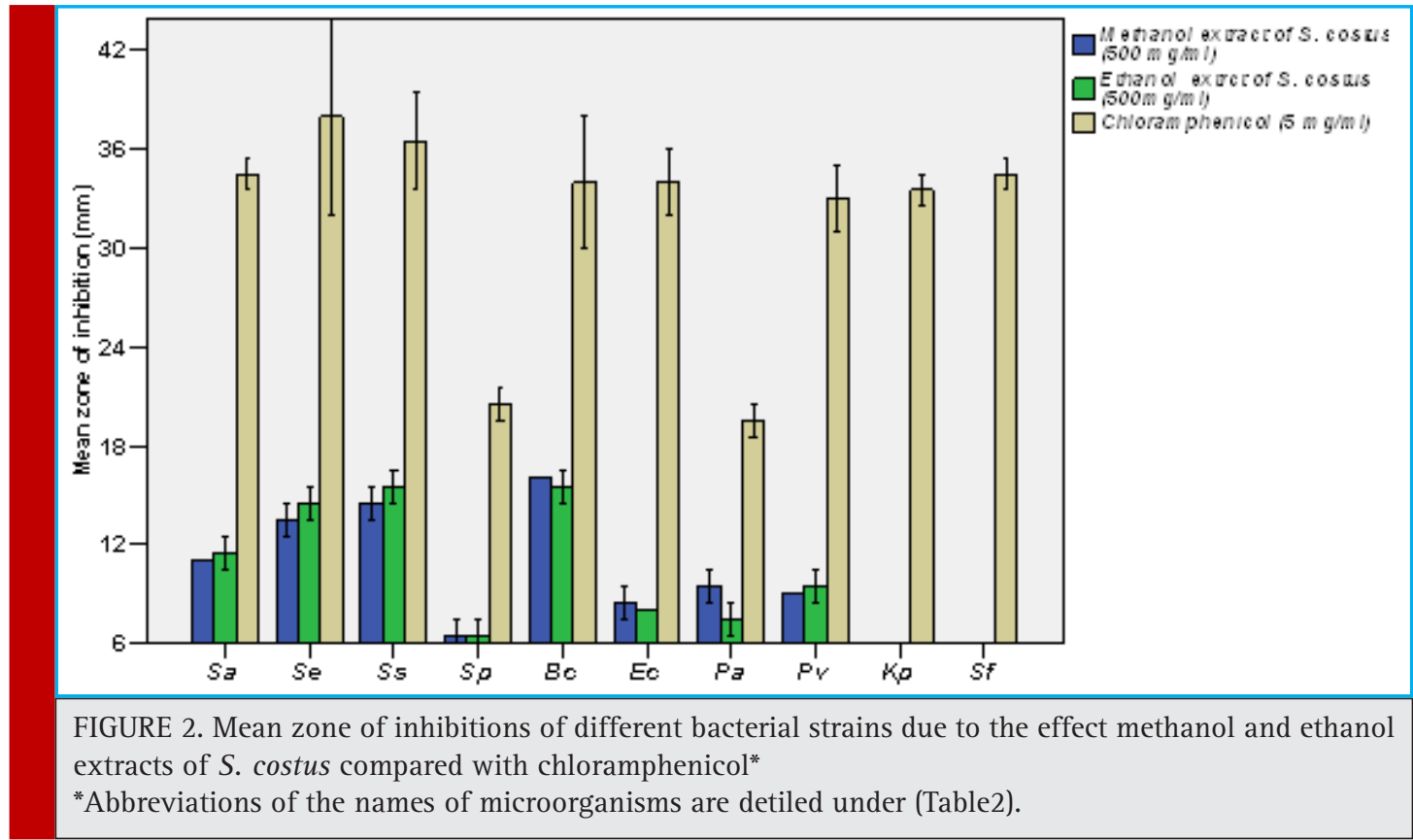




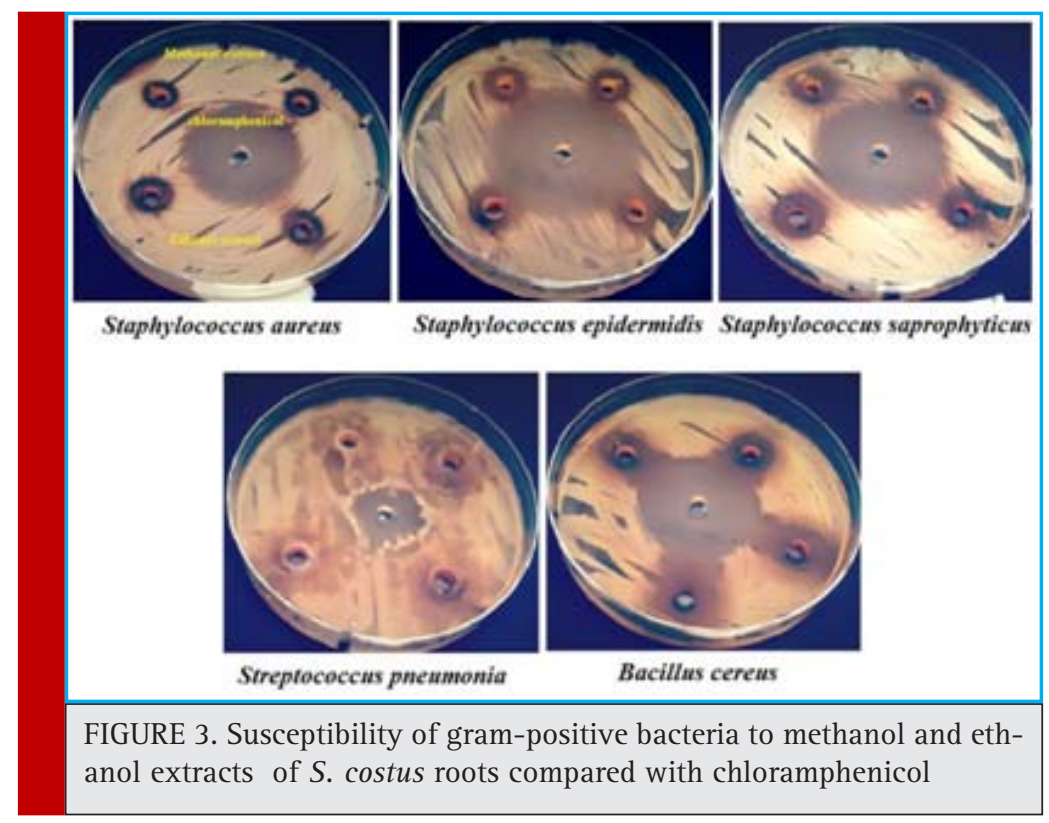

agreement in-partial with the findings of Hasson et al. (2013), in their study they have reported that S. lappa (synonymous S.costus) has exhibited significant level of antibacterial activity against different Gram-positive and Gram-negative pathogenic bacteria, including Staphylococcus aureus, Pseudomonas aeruginosa, Acinetobacter baumanii, Escherichia coli and Klebsiella pneumonia.

After comparing the results of our findings with the results of Hasson et al., 2013, we have concluded that, the former study has used $99.9 \%$ ethanol as a solvent to extract the crude and in our study, we used $70 \%$ Ethanol and used $80 \%$ methanol. It is well known that absolute ethanol can collect non-polar constituents better than $70 \%$ ethanol. Whereas, methanol can collect some nonpolar and polar constituents from the plant materials. The statistical analysis (Paired-Samples T test) showed that, there was no significant difference between antibacterial activity of $70 \%$ ethanolic and $80 \%$ methanolic extracts, which means that the effective antibacterial compounds are present in the non-polar fraction. This consumption is supported with the findings of Pandey et al. (2008), mentioned that, the essential oil of S. costus roots has exhibited better antibacterial effects as compared with the methanolic extract. In addition, S. costus has showed high significant level of antifungal activity

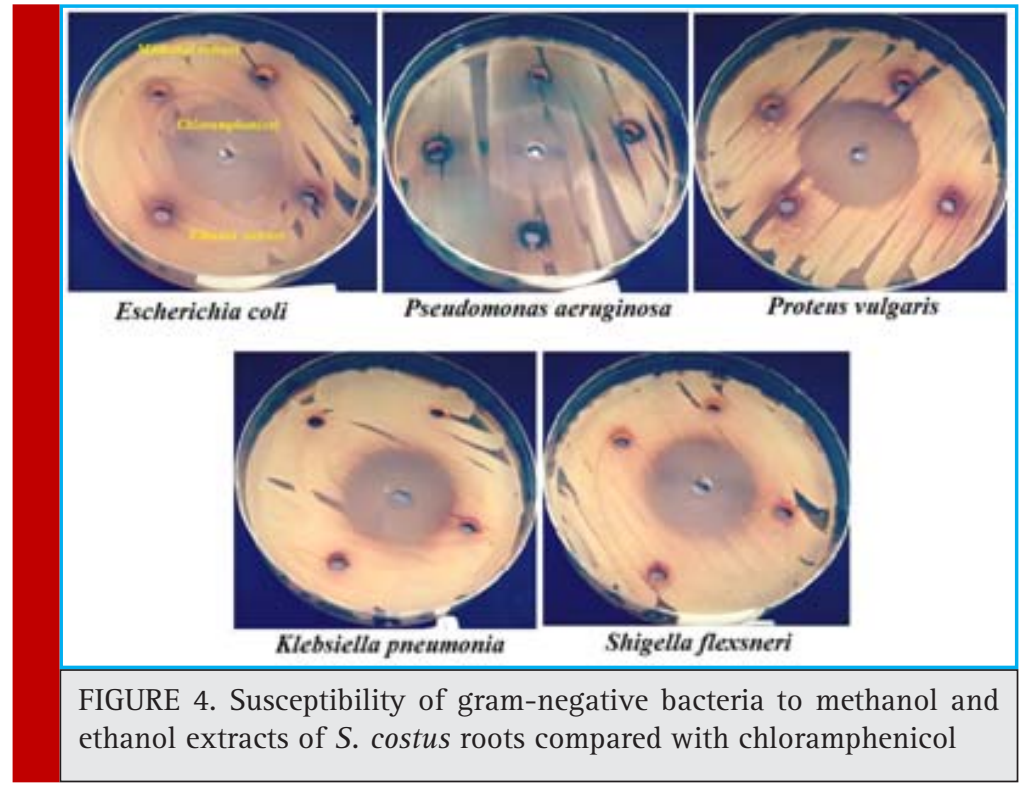




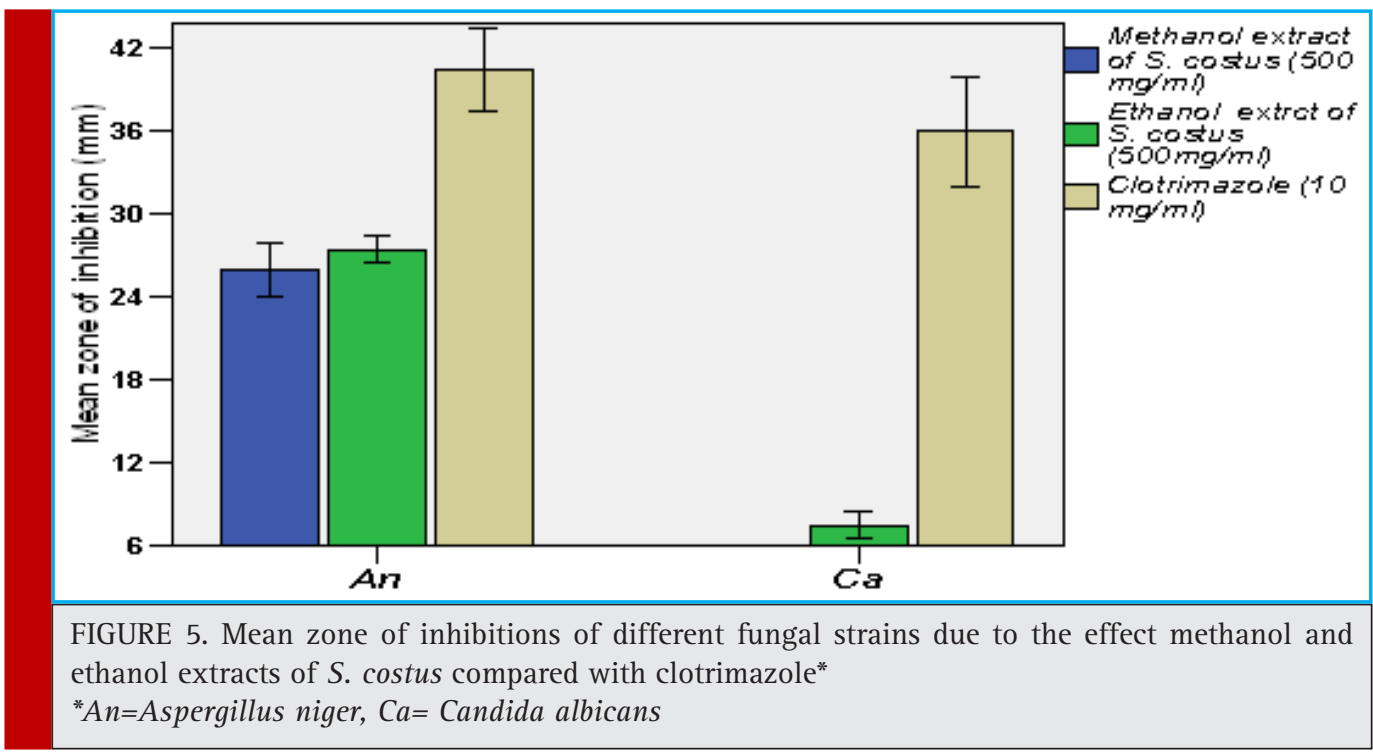

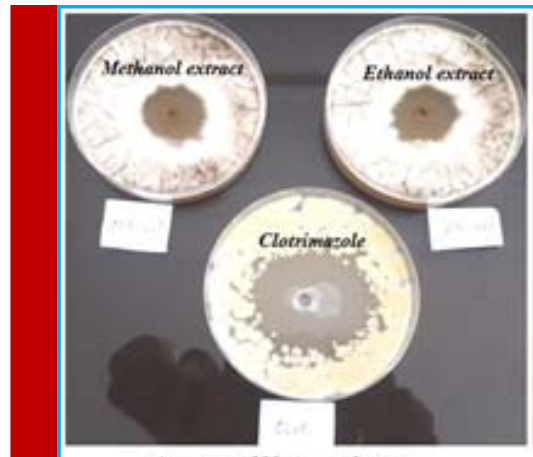

Aspergillus niger

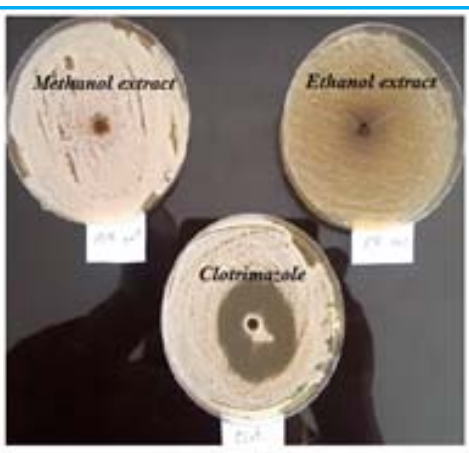

Candida albicans

FIGURE 6. Susceptibility of fungalstrains to methanol and ethanol extracts of $S$. costus roots compared with clotrimazole

against Aspergillus niger ATCC 6275 and weak effect against Candida albicans ATCC 10231.

It disagrees with the findings of Mohamed et al. (2017) who reported good antifungal activity of S. lappa against Candida albicans. This contradiction is related to the solvent used in extraction, as reported by Patil et al. (2009) that, diethyl ether fraction has showed promi- nent fungicidal activity against Candida albicans. However, the antimicrobial activity resulted from the current investigation was not competitor to chloramphenicol or clotrimazole. These referenced antibiotics are present in a pure form (single compound), while the extracts are investigated as a crude. Therefore, the antimicrobial efficacy of $S$. costus roots could be competitor to antibiot-

\begin{tabular}{|c|c|c|c|c|c|c|}
\hline \multirow[t]{2}{*}{ Bacterial strain } & \multicolumn{2}{|c|}{ MIC mg/ml } & \multicolumn{2}{|c|}{$\mathrm{MBC} \mathrm{mg} / \mathrm{ml}$} & \multicolumn{2}{|c|}{ MBC/MIC } \\
\hline & $\mathrm{MeOH}$ & EtOH & $\mathrm{MeOH}$ & EtOH & $\mathrm{MeOH}$ & EtOH \\
\hline Staphylococcus saprophyticus ATCC 43867 & 50 & 50 & 100 & 100 & 2 & 2 \\
\hline Staphylococcus epidermidis ATCC 12228 & 50 & 50 & 200 & 100 & 4 & 2 \\
\hline Bacillus cereus ATCC 10876 & 100 & 50 & 200 & 100 & 2 & 2 \\
\hline Staphylococcus aureus ATCC 29213 & 100 & 50 & 200 & 100 & 2 & 2 \\
\hline
\end{tabular}




\begin{tabular}{|c|c|c|c|c|c|c|}
\hline \multirow[t]{2}{*}{ Fungal strain } & \multicolumn{2}{|c|}{ MIC $\mathrm{mg} / \mathrm{ml}$} & \multicolumn{2}{|c|}{ MFC mg/ml } & \multicolumn{2}{|c|}{ MFC/MIC } \\
\hline & $\mathrm{MeOH}$ & EtOH & $\mathrm{MeOH}$ & EtOH & $\mathrm{MeOH}$ & EtOH \\
\hline Aspergillus niger ATCC 6275 & 50 & 50 & 50 & 50 & 1 & 1 \\
\hline
\end{tabular}

Table 5. Antifeedant activity of ethanolic extract of $S$. costus against 4th instar larvae of $S$. littoralis.

\begin{tabular}{|l|l|l|l|}
\multirow{2}{*}{ Concentration } & \multicolumn{2}{|l|}{ Antifeedant index (\%) \pm SE } & \multirow{2}{*}{ Mean* } \\
\cline { 2 - 3 } & \multicolumn{2}{|l|}{ Days post-treatment } & \\
\cline { 2 - 3 } & 1 st & 2 nd & \\
\hline $0.6 \%$ & $28.39 \pm 4.22 \mathrm{e}$ & $26.01 \pm 1.64 \mathrm{~d}$ & $27.20 \%$ \\
\hline $1.25 \%$ & $39.54 \pm 3.27 \mathrm{~cd}$ & $39.75 \pm 5.50 \mathrm{c}$ & $39.64 \%$ \\
\hline $2.5 \%$ & $35.16 \pm 3.36 \mathrm{de}$ & $38.34 \pm 3.21 \mathrm{c}$ & $36.75 \%$ \\
\hline $5 \%$ & $46.58 \pm 1.96 \mathrm{c}$ & $43.03 \pm 2.52 \mathrm{bc}$ & $44.80 \%$ \\
\hline $10 \%$ & $58.34 \pm 4.75 \mathrm{~b}$ & $50.90 \pm 2.67 \mathrm{~b}$ & $54.60 \%$ \\
\hline $20 \%$ & $85.36 \pm 2.24 \mathrm{a}$ & $70.16 \pm 3.23 \mathrm{a}$ & $77.76 \%$ \\
\hline $\begin{array}{l}|l| \\
\text { "Data are expressed as mean } \pm \text { SE (n=5), total mean of each treatment } \\
\text { at different time intervals, values were analyzed by one-way ANOVA, } \\
\text { where means within each column followed by different letters are } \\
\text { significantly different (P< } 0.05 \text { by LSD). }\end{array}$ \\
\hline
\end{tabular}

ics if the bioactive compound (s) isolated and studied in a future studies. This hypothesis is boosted by the results of MIC, MBC and MFC as shown in (Tables 3 and 4), which revealed that, the methanolic extract was bacteriostatic to Staphylococcus saprophyticus, Staphylococcus epidermidis, Bacillus cereus and Staphylococcus aureus at 50, 50, 100 and $100 \mathrm{mg} / \mathrm{ml}$, respectively; and the bactericidal activity was at 100, 200, 200, 200 $\mathrm{mg} / \mathrm{ml}$, respectively. As well, the ethanolic extract was bacteriostatic to Staphylococcus saprophyticus, Staphylococcus epidermidis, Bacillus cereus and Staphylococcus aureus at 50, 50, 50 and $50 \mathrm{mg} / \mathrm{ml}$, respectively; and the bactericidal activity was detected at 100, 100, 100, $100 \mathrm{mg} / \mathrm{ml}$, respectively. In addition, the methanolic and ethanolic extracts were bacteriostatic and bactericidal to Aspergillus niger at $50 \mathrm{mg} / \mathrm{ml}$. The values of $\mathrm{MBC} /$ MIC were ranging between 2-4 for bacterial strains and 1 for fungal strain. Djeussi (2013) has stated that, the

\begin{tabular}{|c|c|c|c|c|c|}
\hline Treatments & Time & $\begin{array}{l}\text { Average weight } \\
\text { (mg/larva) }\end{array}$ & $\begin{array}{l}\text { Difference* } \\
\text { (mg/larva) }\end{array}$ & Starvation $(\%)$ & Average \\
\hline 0.6 & $\begin{array}{l}0 \mathrm{~min} \\
24 \mathrm{~h} \\
48 \mathrm{~h}\end{array}$ & $\begin{array}{l}63.13 \\
74.30 \\
93.62\end{array}$ & $\begin{array}{l}------- \\
+11.17 \\
+30.49\end{array}$ & $\begin{array}{l}------- \\
25.09 \\
24.18\end{array}$ & $24.63 \%$ \\
\hline 1.25 & $\begin{array}{l}0 \mathrm{~min} \\
24 \mathrm{~h} \\
48 \mathrm{~h}\end{array}$ & $\begin{array}{l}69.10 \\
76.24 \\
84.12\end{array}$ & $\begin{array}{l}-------- \\
+7.14 \\
+15.02\end{array}$ & $\begin{array}{l}------- \\
42.38 \\
52.05\end{array}$ & $47.21 \%$ \\
\hline 2.50 & \begin{tabular}{|l}
$0 \mathrm{~min}$ \\
$24 \mathrm{~h}$ \\
$48 \mathrm{~h}$
\end{tabular} & $\begin{array}{l}60.11 \\
70.00 \\
70.73\end{array}$ & $\begin{array}{l}-------- \\
+9.89 \\
+10.62\end{array}$ & $\begin{array}{l}------- \\
30.58 \\
59.98\end{array}$ & $45.28 \%$ \\
\hline 5 & $\begin{array}{l}0 \mathrm{~min} \\
24 \mathrm{~h} \\
48 \mathrm{~h}\end{array}$ & $\begin{array}{l}60.83 \\
64.20 \\
72.31\end{array}$ & $\begin{array}{l}------- \\
+3.37 \\
+11.48\end{array}$ & $\begin{array}{l}------- \\
58.55 \\
58.43\end{array}$ & $58.49 \%$ \\
\hline 10 & $\begin{array}{l}0 \mathrm{~min} \\
24 \mathrm{~h} \\
48 \mathrm{~h}\end{array}$ & $\begin{array}{l}68.23 \\
64.75 \\
77.80\end{array}$ & $\begin{array}{l}------- \\
-3.48 \\
+9.57\end{array}$ & $\begin{array}{l}------- \\
87.94 \\
61.87\end{array}$ & $74.90 \%$ \\
\hline 20 & $\begin{array}{l}0 \mathrm{~min} \\
24 \mathrm{~h} \\
48 \mathrm{~h}\end{array}$ & $\begin{array}{l}68.00 \\
63.25 \\
65.78\end{array}$ & $\begin{array}{l}------- \\
-4.75 \\
-2.22\end{array}$ & $\begin{array}{l}------- \\
93.39 \\
83.11\end{array}$ & $88.25 \%$ \\
\hline Control & \begin{tabular}{|l}
$0 \mathrm{~min}$ \\
$24 \mathrm{~h}$ \\
$48 \mathrm{~h}$
\end{tabular} & $\begin{array}{l}68.10 \\
85.12 \\
112.01\end{array}$ & $\begin{array}{l}-------- \\
+17.02 \\
+43.91\end{array}$ & $\begin{array}{l}\text {------- } \\
\text {------- } \\
-------\end{array}$ & $\begin{array}{l}\text {------- } \\
\text {------- } \\
-------\end{array}$ \\
\hline Starved larvae & $\begin{array}{l}0 \text { min } \\
24 \mathrm{~h} \\
48 \mathrm{~h}\end{array}$ & $\begin{array}{l}61.68 \\
55.39 \\
50.09\end{array}$ & $\begin{array}{l}-------- \\
-6.29 \\
-11.59\end{array}$ & $\begin{array}{l}\text {------- } \\
\text {------- } \\
-------\end{array}$ & $\begin{array}{l}\text {------- } \\
\text {------- } \\
-------\end{array}$ \\
\hline
\end{tabular}


plant extract is a bactericidal when the ratio of $\mathrm{MBC} /$ MIC equals 4 and bacteriostatic when MBC/MIC ratio is $>4$. Accordingly, $S$. costus roots may possess new natural antimicrobial agents that require isolation of these novel and natural bioactive molecules.

\section{ANTIFEEDANT PROPERTIES}

The antifeedant potential results of the ethanolic extract of $S$. costus on the larvae of Spodoptera littoralis are presented in (Table 5), the crude methanol extract exhibited antifeedant effect on the $4^{\text {th }}$ instar larvae of $S$. littoralis. The antifeedant activity are varying from $27.2 \%, 39.64 \%, 36.75 \%, 44.8 \%, 54.6$ to $77.76 \%$ at 0.6 , $1.25,2.5,5,10$ and 20\% concentrations, respectively. It was noticed that the antifeedant activity on the larvae increased by days in all concentrations after treatment. Data in (Table 6) shows the starvation percentage of the $4^{\text {th }}$ instar larvae of $S$. littoralis treated with the ethanolic extract of $S$. costus. The starvation percentage same as antifeedant activity which increased with the increasing of the concentration during 48 hours. The root of S. lappa which have the essential oil and the alkaloid considered as insect repellent (Kapoor, 2001). The Costunolide that isolated from root extract of S. lappa showed 80\% antifeedant activity to citrus pest Papilio demoleus (Vattikonda et al., 2014). The plant extract of of S. costus may be useful for effective control of $S$. littoralis at larval stages.

\section{CONCLUSION}

Roots of Saussurea costus (S. costus) are widely used in the traditional medicine; it is frequently mentioned in the Islamic medicine as well as ancient Indian and Chinese medicine. the current investigation revealed the presence of many bioactive phytochemical molecules, antimicrobial activity, and antifeedant effect against Spodoptera littoralis larvae, which offers a scientific basis for traditional uses of $S$. costus roots as antimicrobial and insect repellent. We recommend further future studies using different solvents and extraction systems as we assume that there are perhaps more bioactive compounds in the non-polar or aromatic fraction. Moreover, it is worthy to separate and identify these bioactive compounds from the roots of $S$. costus in order to get new natural and effective drugs.

\section{SOURCE OF SUPPORT}

Nil

\section{CONFLICT OF INTEREST}

None declared

\section{REFERENCES}

Abdallah, E. M. (2014): Antimicrobial properties and phytochemical constituents of the methanol extracts of Euphorbia retusa Forssk. and Euphorbia terracina L. from Saudi Arabia. South Asian J. Exp. Biol. 4(2): 48-53.

Abdel-Mageed, M. I., Shaaban, A. M. and Zidan, Z. H. (1975): The effectiveness of dursban, Du-Ter brestan and their combination against the cotton leafworm Spodoptera littoralis (Boisd.). Bull. Ent. Soc. Egypt, Econ. Ser. 9:283-292.

Abdel-Rahim, E.F.M. and Azab, A.M.A. (2008): Bio-residual activity of some conventional and inconventional insecticides against field strain cotton leaf worm, Spodoptera littoralis (Boisd). Egypt. J. Agric. Res. 86: 2141-2155.

Adham, F.K., Rashad, E.M.,Shoukry, I.F. and Nasr, E.E. (2009): Host plants shifting affects the biology and biochemistry of Spodoptera littoralis (boisd.) (lepidoptera: noctuidae). Egypt. Acad. J. Boil. Sci. 2: 63- 71.

Ahmad, M., Khan, M. A., Marwat, S. K., Zafar, M. and Khan, M. A. (2009): Useful Medicinal Flora Enlisted in Holy Quran and Ahadith. American-Eurasian J. Agric. Environ. Sci. 5(1): 126-140.

Choulhary, G.P. (2015): Phytochemical and pharmacological study of Saussurea lappa Clarke: a review. European J. Pharmaceu. Med. Res. 2(7): 120-125.

Djeussi, D. E., Noumedem, J.A., Seukep, J.A., Fankam, A.G., Voukeng, I. K., Tankeo, S. B., et al. (2013): Antibacterial activities of selected edible plants extracts against multidrug-resistant Gram-negative bacteria. BMC Complement. Altern. Med. 13: 164.

Ekor, M. (2013): The growing use of herbal medicines: issues relating to adverse reactions and challenges in monitoring safety. Front. Pharmacol. 4: 177.

El-Torky, H. M. (2008): Physico-chemical studies on formulated plant extracts and their effect on Spodoptera littoralis (Boisd.) (Lepidoptera: Noctuidae). Bull. Ent. Soc. Egypt. Econ. Ser. 34: 111-118.

El-Zoghby, F. A., Salem, M.H., Gadelhak, G.G. and El-Sabrout, A.M. (2011): Effect of Melilotus indica crude extracts and cascade (IGR) on Spodoptera littoralis (Lepidoptera: Noctuidae) reproductive organs. Bull. Ent. Soc. Egypt. Econ. Ser. 37: 121-136.

Fan, W., Liu, F., Bligh, S.W.A., Shi, S. and Wang, S. (2014): Structure of a homofructosan from Saussurea costus and anticomplementary activity of its sulfated derivatives. Carbohyd. Polym. 105: 152-1

Ghasham, A.A., Muzaini, M.A., Qureshi, K.A., Elhassan, G.O., Khan, R.A., Farhana, S.A., Hashmi, S., El-Agamy, E. and Abdallah, W.E. (2017): Phytochemical Screening, Antioxidant and Antimicrobial Activities of Methanolic Extract of Ziziphus mauritiana Lam. Leaves Collected from Unaizah, Saudi Arabia. Int. J. Pharm. Res. Allied Sci. 6(3):33-46.

Hassan, A., Rahman, S., Deeba, F. and Mahmud, S.C. (2009): Antimicrobial activity of some plant extracts having hepatoprotective effects. J. Med. Plants Res. 3(1): 020-023.

Hasson, S.S.A., Al-Balushi, M.S., Alharthy, K., Al-Busaidi, J.Z., Aldaihani, M.S., Othman, M.S., Said, E.A., Habal, O., Sallam, 
T.A., Aljabri, A. and Idris, M.A. (2013): Evaluation of antiresistant activity of Auklandia (Saussurea lappa) root against some human pathogens. Asian Pac. J. Trop. Biomed. 3(7): 557562.

Julianti, T., Hata, Y., Zimmermann, S., Kaiser, M., Hamburger, M. and Adams, M. (2011): Antitrypanosomal sesquiterpene lactones from Saussurea costus. Fitoterapia 82:955-959.

Kamaraj, C., Abdul Rahuman, A., Mahapatra, A., Bagavan, A. and Elango, G. (2010): Insecticidal and larvicidal activities of medicinal plant extracts against mosquitoes. Parasitol. Res. 107: 1337-1349.

Kandil, M.A., Abdel-Aziz,N.F. and Sammour, E.A. (2003). Comparative toxicity of chlorfluazuran and leufenron against cotton leafworm Spodoptera littoralis (Boisd). Egypt J. Agric. Res. 2: 645-661.

Kapoor, L.D. (2001): Handbook of Ayurvedic Medicinal Plants. Washington D. C: CRS Press; 2001.

Mohamed, A., Aldaw, M., Ismail, E., Abu-algasim A. and Karar, E. (2017): Evaluation of antimicrobial activity of different solvent extracts of Saussurea lappa, World J. Pharm. Pharmaceu. Sci. 6(9): 12-18.

Mostafa, O. K. (1969): Studies on antifeeding and repellents to economic lepidoptera. M.Sc. Thesis, Faculty of Agriculture Cairo University, Egypt, pp. 65-68.

Omojate, G. C., Enwa, F. O., Jewo, A. O. and Eze, C, 0. (2014): Mechanisms of antimicrobial actions of phytochemicals against enteric pathogens - a review. J. Pharm. Chem. Biol. Sci. 2(2):77-85.

Pandey, M.M., Rastogi, S. and Rawat, A.K.S. (2007): Saussurea costus: Botanical, chemical and pharmacological review of an ayurvedic medicinal plant. J. Ethnopharma. 110: 379-390.

Pandey, M.M., Singh, M., Rastogi, S. and Rawat, A.K.S. (2008): Antimicrobial activity of methanolic extract and oil of Saussurea costus roots. Nigerian J. Nat. Prod. Med. 12:95-98.

Patil, S.M., Patil, M.P., Sapkale, G.N. and Umbare, R.P. (2009): Antimicrobial activity of Saussurea lappa Clarke roots. Res. J. Pharmacog. Phytochem. 1(1): 51-53.
Philip, K., Malek, S.N.A., Sani, W., Shin, S.K., Kumar, S., Lai, H.S., Serm, L.G. and Rahman, S.N.S.A. (2009): Antimicrobial activity of some medicinal plants from Malaysia. American J. Appl. Sci. 6: 1047-1058.

Qazi, M.A. and Molvi, K.I. (2016): Herbal Medicine: A Comprehensive Review. Inter. J. Pharmace. Res. 8(2): 1-5.

Rizk, G.A., Hashem H.F. and Mohamed, S.A. (2010): Plants in pest control.2-Evaluation of some plant extracts against the cotton leaf worm, Spodoptera littoralis (Boisd.). Bull. Ent. Soc. Egypt. Econ. Ser. 36: 213-222.

Robinson, A., Kumar, T.V., Sreedhar, E., Naidu, V.G.M., Krishna, S.R., Babu, K.S., Srinivas, P.V.M and Rao, J.M. (2008): A new sesquiterpene lactone from the roots of Saussurea lappa: Structure-anticancer activity study. Bioorg. Med. Chem. Let. 18: 4015-4017.

Sasidharan, S., Chen, Y., Saravanan, D., Sundram, K.M. and Yoga Latha, L. (2011): Extraction, isolation and characterization of bioactive compounds from plants' extracts. Afr. J. Tradit. Complement. Altern. Med. 8(1): 1-10.

Shah, R. (2006): Nature's Medicinal plants of Uttaranchal: (Herbs, Grasses \&t Ferns). Vol. I and II. Gyanodaya Prakashan, Nanital, Uttarakhand. India.

Vattikonda,S. R., Amanchi, N. R. and Sangam, S. R. (2015): Effect of Costunolide a plant product of Saussurea lappa on feeding behaviour of Papilio demoleus L. (Lepidoptera: Papilionidae) Larvae. Res. J. Recent Sci. 4 (7): 55-58.

Wani, B.A., Wani, F.M., Khan, A., Bodha, R.H., Mohiddin, F.A. and Hamid, A. (2011): Some herbs mentioned in the Holy Quran and Ahadith and their medicinal importance in contemporary times. J. Pharm. Res. 4(11): 3888-3891.

White, L. (1995): Chemical control. Integrated management of insects in stored products. Dekker, Inc; New York. Basel. Hong Kong, pp. 287- 330.

Zahra, K,, Tabassum, S., Sabir, S., Chaudhari, S.K., Arshad, M., Qureshi, R. and Amgad, M.S. (2014): A review of therapeutic potential of Saussurea lappa-An endangered plant from Himalaya. Asian Pac. J. Trop. Med. 7(S1): S60-S69. 